\title{
JURNAL ILMIAH KEBIDANAN

\section{ANALISIS PEMBERIAN TABLET TAMBAH DARAH DAN POLA KONSUMSI MAKANAN SUMBER ZAT BESI TERHADAP KADAR HB REMAJA PUTRI ANEMIA GIZI BESI DI SEKOLAH MENENGAH ATAS SWASTA YPWI MUSLIMAT KOTA JAMBI}

\author{
Aryani Puspasari ${ }^{1}$, Susmita ${ }^{2}$ \\ ${ }^{1}$ STIK Bina Husada, Palembang, Indonesia \\ ${ }^{2}$ STIK Bina Husada, Palembang, Indonesia \\ Email: ${ }^{1}$ aryanipuspassari@gmail.com ${ }^{2 *}$ susmitasyarief@gmail.com
}

\begin{abstract}
Abstrak
Anemia masih merupakan masalah pada wanita Indonesia sebagai akibat kekurangan zat besi dan asam folat dalam tubuh serta faktor lain seperti penyakit infeksi, cacingan dan penyakit kronis. Remaja putri mempunyai resiko paling tinggi menderita anemia, karena pada masa ini terjadi peningkatan kebutuhan gizi serta adanya mensturasi, selama masa haid kehilangan zat besi rata-rata $24 \mathrm{mg}$. Desain penelitian kuantitatif dengan rancangan Quasiexperiment. Populasi semua remaja putri sebanyak 106 orang di SMAS YPWI Muslimat Kota Jambi. Pengambilan sampel secara purposive sampling sesuai kriteria inklusi dengan membandingkan kelompok Kasus yang berjumlah 15 orang dan kelompok Kontrol yang berjumlah 15 orang dilaksanakan pada tanggal 20Agustus s/d 20 November 2016.Analisa data dengan Uji T Pre and Post test.Hasil penelitian ada pengaruh kadar energi,kadar protein dan tidak ada pengaruh kadar lemak, Fedan kadar hemoglobin sebelum dan sesudah dilakukan intervensi pada remaja putri di Sekolah Menengah Atas Swasta YPWI Muslimat Kota Jambi Tahun 2016. Persamaan garis regresi 0,001 berarti dapat disimpulkan secara keseluruhan sudah signifikan. Diharapkan agar instansi terkait bekerja sama dengan lintas sektoral Dinas Kesehatan dalam rangka menurunkan prevalensi kejadian anemia pada remaja putri dengan melakukan komunikasi, informasi ,edukasi serta motivasi tentang upaya pencegahan anemia pada remaja putri sehingga kejadian anemia pada remaja putri dapat dicegah.
\end{abstract}

Kata Kunci : Tablet tambah darah, anemia, pola konsumsi, hemoglobin.

\begin{abstract}
Anemia remains a problem in Indonesian women as a result of iron deficiency and folic acid in the body as well as other factors such as infectious diseases, worms and chronic diseases. Young women have the highest risk of anemia, because at this time there is an increase in nutritional needs and the presence of mensturasi, during the menstrual period of iron loss an average of $24 \mathrm{mg}$. Quantitative research design with Quasi experiment design. The population of all teenage girls as many as 106 people in SMAS YPWI Muslimat Jambi City. Sampling by purposive sampling according to the inclusion criteria by comparing the Case group of 15 people and the control group consisting of 15 people was conducted on 20 August to 20 November 2016. Data analysis with T test Pre and Post Test. The result of the research is the influence of energy level, protein level and no effect of fat content, Fe and hemoglobin level before and after intervention in adolescent girls at YPWI Muslimat Private High School Jambi City 2017. Equation of 0,001 Can be summed up as a whole is already significant. It is expected that related institutions will work together with cross-sectoral Health Office in order to decrease the prevalence of anemia incidence in adolescent girls by conducting communication, information, education and motivation about prevention of anemia in young women so that the incidence of anemia in adolescent girls can be prevented.

Keyword : blood booster drugs, anemia, daily diet, hemoglobine
\end{abstract}




\section{JURNAL ILMIAH KEBIDANAN \\ E-ISSN 2774-467I}

\section{Pendahuluan}

Anemia masih merupakan masalah pada wanita Indonesia sebagai akibat kekurangan zat besi dan asam folat dalam tubuh serta faktor lain seperti penyakit infeksi, cacingan dan penyakit kronis.Dibandingkan dengan semua golongan umur, wanita terutama remaja putri mempunyai resiko paling tinggi menderita anemia, karena pada masa ini terjadi peningkatan kebutuhan serta adanya mensturasi. Selama masa haid kehilangan zat besi rata-rata 24mg ( Almatsier,sunita. 2009). Menurut World Health Organization (WHO) (2013) prevalensi anemia di dunia40-88\% dan 25-45 \% remaja putri mengalami anemia berbagai tingkatan/ grade penderita anemia defisiensi besi zat besi tingkat ringan sampai berat di Asia Tenggara (Briawan, D. 2008).

Di Indonesia prevalensi anemia masih cukup tinggi. Jumlah penduduk usia remaja ( 10-19 tahun) di Indonesia sebesar 26,2\% yang terdiri dari 50,9\% laki-laki dan 49,1\% perempuan (Kemenkes RI, 2013). Menurut hasil Riskesdas Kemenkes RI tahun 2013, prevalensi anemia pada remaja di Indonesia yaitu $21,7 \%$ dengan penderita anemia umur 5-14 tahun sebesar 26,4\% dan 22,7\% penderita berumur15-24 tahun dimana prevalensi anemia pada perempuan relative lebih tinggi $(23,9 \%)$ jika dibandingkan dengan laki-laki (18,4\%).

Remaja putri menderita anemia, hal ini dapat dimaklumi karena masa remaja adalah masa pertumbuhan yang sangat membutuhkan zat gizi lebih tinggi termasuk zat besi. Disamping itu remaja putri mengalami menstruasi setiap bulan sehingga membutuhkan zat besi lebih tinggi, sementara jumlah makanan yang di konsumsi lebih rendah dari pada pria, karena faktor ingin langsing ( body image), pantang makanan tertentu dan kebiasaan makan yang salah seperti mengkonsumsi jajanan atau pun makanan kecil sebagai pengganti makanan pokok juga merupakan penyebab terjadinya anemia pada remaja putri (Hardiansyah, Irawati. 2012).

Di Kota Jambi angka kejadian anemia pada remaja dari tahun 2013 sebanyak 2,3 \% meningkat menjadi 14,3\% pada Tahun 2016. Survey awal yang penulis lakukan pada tanggal 20 Juli 2016 terhadap 10 orang remaja putri, terdapat 4 orang mengatakan mudah lesu, dan lemas sehingga kurang semangat dalam belajar dan memiliki gejala klinis pucat pada konjungtiva , 3 orang mengatakan sering pusing dan mata berkunang-kunang, dan hanya 3 orang remaja putri yang mengatakan tidak mudah lesu, lemas, dan mendapatkan konsentrasi baik dalam belajar.Kondisi anemia dapat mempengaruhi gairah belajar dan konsentrasi belajar. Selain itu, daya tahan tubuh akan menurun sehinggga mudah terserang penyakit.

Berdasarkan fenomena di atas, maka penulis tertarik untuk melakukan sebuah penelitian ilmiah yang berjudul "Analisis Pemberian Tablet Tambah Darah Terhadap Kadar Haemoglobine (Hb) dan Pola Konsumsi Sumber Zat Besi Pada Makanan Sehari pada Remaja Putri Anemia Gizi Besi di Sekolah Menengah AtasSwasta YPWI Muslimat Wilayah Kerja Puskesmas Tanjung Pinang Kota Jambi Tahun 2016".

\section{Metode Penelitian}

Penelitian ini merupakan penelitian kuantitatif dengan rancangan penelitian Quasiexperiment denganyang memiliki perlakuan dan unit-unit eksperimen namun tidak menggunakan penempatan secara acak (randomisasi). Penelitian ini merupakan bagian dari metode kuantitatif, dan memiliki ciri khas tersendiri terutama dengan adanya kelompok kontrol dan membandingkan kelompok intervensi dan kelompok kontrol. Jenis penelitian ini dipakai karena penelitian lapangan, dimana disain tidak mempunyai pembatasan yang ketat terhadap randomisasi atau tidak ada randomisasi sama sekali.(Riyadi H. 2001.)

Sehingga diambil sampel secara purposive sampling untuk kelompok perlakuan adalah 15 orang dan sampel untuk kelompok kontrol adalah 15 orang.Dengan kriteria inklusi yang telah ditentukan peneliti.Analisa data dengan Uji T Independent pre and post design. Dilaksanakan selama 12 minggu terhitung mulai tanggal 20 Agustus s/d 20 November 2016. Penelitian ini dilakukan di Sekolah Menengah Atas Swasta YPWI Muslimat Kota Jambi. 


\section{Hasil dan Pembahasan}

1. Analisis Pengaruh kadar Energi sebelum dan sesudah di Sekolah Menengah Atas Swasta YPWI Muslimat Kota Jambi Tahun 2016.

Tabel 1

Distribusi Rata-rata Kadar Energi Responden Menurut Pengukuran Sebelum dan Sesudah

\begin{tabular}{lccccc}
\hline \hline \multicolumn{1}{c}{ Variabel } & Mean & SD & SE & P Value & N \\
\hline Energi Sebelum & 1819.42 & 112.672 & 20.571 & 0.002 & 30 \\
Energi Sesudah & 1823.30 & 110.879 & 20.244 & & \\
\hline \hline
\end{tabular}

Kecukupan energi, kecukupan karbohidrat seseorang dipengaruhi oleh ukuran tubuh (berat badan), usia atau tahap pertumbuhan dan perkembangan, dan aktifitas fisik. Ukuran tubuh dalam arti masa otot yang semakin besar dan aktifitas fisik yang semakin tinggi berimplikasi pada kecukupan karbohidrat yang semakin tinggi.Masa remaja merupakan masa pertumbuhan yang pesat sehingga asupan gizi yang ade kuat sangat diperlukan untuk mencapai tumbuh kembang yang optimal.

2. Analisis Kadar Protein Sebelum dan Sesudah Dilakukan Intervensidi Sekolah Menengah Atas Swasta YPWI Muslimat Kota Jambi Tahun 2017.

Tabel 2

Distribusi Rata-rata Kadar Protein Responden Menurut Pengukuran Sebelum dan Sesudah Intervensi

\begin{tabular}{lccccc}
\hline \multicolumn{1}{c}{ Variabel } & Mean & SD & SE & P Value & N \\
\hline protein Sebelum & 47.03 & 3.969 & 0.725 & 0.000 & 30 \\
protein Sesudah & 53.02 & 5.126 & 0.936 & & \\
\hline \hline
\end{tabular}

Protein terdiri dari asam amino. Disamping menyediakan asam amino esensial, protein juga mensuplai energi dalam keadaan energi terbatas dari karbohidrat dan lemak.Asam amino esensial meliputi Histidine, Isoleucine, Leucine,Lysine,Methionine, Cysteine, Phinilalanine, Tyrosine, Threonine, Tryptophan dan Valine. Pada umumnya empat asam amino yang sering defisit dalam makanan anak-anak adalah Lysine, Methionine+Cysteine,Threonine+Tryptophan (FAO/WHO, 1985).

Protein atau asam amino esensial berfungsi terutama sebagai katalisator, pembawa, pengerak, pengatur, ekpresigenetik, neurotransmitter, penguat struktur, penguat immunitas dan untuk pertumbuhan (Arisman. 2004).

3. Analisis Kadar Lemak Sebelum dan Sesudah Dilakukan Intervensi.

Tabel 3

Distribusi Rata-rata Kadar Lemak Responden Menurut Pengukuran Sebelum dan Sesudah Intervensi

\begin{tabular}{lccccc}
\hline \multicolumn{1}{c}{ Variabel } & Mean & SD & SE & P Value & $\boldsymbol{N}$ \\
\hline Lemak Sebelum & 58.03 & 3.921 & 0.716 & 0.559 & 30 \\
Lemak Sesudah & 57.96 & 3.953 & 0.722 & & \\
\hline \hline
\end{tabular}

Di dalam tubuh lemak juga berfungsi sebagai penyuplai energi, membantu absorpsi vitamin yang larut lemak,sumber asam lemak essensial yang tidak dapat dihasilkan tubuh dan harus disuplai dari makanan,sebagai bahan baku hormon juga sanagat berpengaruh terhadap proses fisiologis di dalam tubuh seperti horman seks, lemak juga berfungsi sebagai isolator untuk membantu mempertahankan suhu tubuh dan sebagai bantalan yang melindungi organ-organ seperti bola mata,ginjal dan organ lain ( Siti Maryam,2016). 


\section{JURNAL ILMIAH KEBIDANAN \\ E-ISSN 2774-4671}

Seperti halnya kecukupan energi, kecukupan lemak seseorang juga dipengaruhi oleh dipengaruhi oleh ukuran tubuh(terutama berat badan) usia atau tahap pertumbuhan dan perkembangan dan aktifitas (Siti Maryam,2016).

4. Analisis kadar Fe Sebelum dan Sesudah dilakukan Intervensidi Sekolah Menengah Atas Swasta YPWI Muslimat Kota Jambi Tahun 2016.

Tabel 4

Distribusi Rata-rata Kadar Fe Responden Menurut Sebelum dan Sesudah Dilakukan Intervensi

\begin{tabular}{|c|c|c|c|c|c|}
\hline Variabel & Mean & $S D$ & $S E$ & $P$ Value & $N$ \\
\hline Fe Sebelum & 21.20 & 2.820 & 0.515 & 0.083 & 30 \\
\hline Fe Sesudah & 22.41 & 3.220 & & & \\
\hline
\end{tabular}

Zat besi adalah mineral yang dibutuhkan untuk membentuk sel darah merah (hemoglobin).Selain itu, mineral ini juga berperan sebagai komponen untuk membentuk mioglobin (protein yang membawa oksigen ke otot), kolagen (protein yang terdapat di tulang, tulang rawan, dan jaringan penyambung), serta enzim.Zat besi juga berfungsi dalam sistim pertahanan tubuh. Perbedaan kadar besi sebelum dan sesudah terjadi secara akut seperti dalam penelitian Rogers et al dapat disebabkan oleh tiga hal, yaitu akibat eksresi keringat yang ekstrim, level feritin serum yang kurang serta aktivitas fisik yang berat (Kemenkes RI,2014).

5. Analisis kadar $\mathrm{Hb}$ sebelum dan sesudah di Sekolah Menengah Atas Swasta YPWI Muslimat Kota Jambi Tahun 2016.

Tabel 4

Distribusi Rata-rata Kadar Hb Responden Sebelum dan Sesudah dilakukan Intervensi

\begin{tabular}{|c|c|c|c|c|c|}
\hline Variabel & Mean & $S D$ & $S E$ & $P$ Value & $N$ \\
\hline $\mathrm{Hb}$ Sebelum & 10.99 & 0.822 & 0.150 & 0.062 & 30 \\
\hline Hb Sesudah & 11.49 & 1.015 & 0.185 & & \\
\hline
\end{tabular}

\section{Analisis Multivariat}

Dari hasil uji analisis multivariat dengan uji regresi linier didapatkan nilai R Square sebesar 0,489, artinya kelima variabel indevenden dapat menjelaskan variabel kadar $\mathrm{Hb}$ sebesar $48,9 \%$ sedangkan sisanya dijelaskan oleh variabel lain dari hasil uji statistik pada kotak anova didapatkan $p$ value $=0,001$ berarti persamaan garis regresi secara keseluruhan sudah signifikan.

\section{Seleksi Bivariat}

Seleksi Bivariat Variabel Bebas

\begin{tabular}{|c|c|c|}
\hline No. & Variabel Bebas & $\overline{\rho \rho \text { value }}$ \\
\hline 1. & Umur & 0.198 \\
\hline 2. & Kadar Energi & 0.232 \\
\hline 3. & Kadar Protein & 0.014 \\
\hline 4. & Kadar Lemak & 0.152 \\
\hline 5. & Kadar Fe & 0.486 \\
\hline
\end{tabular}




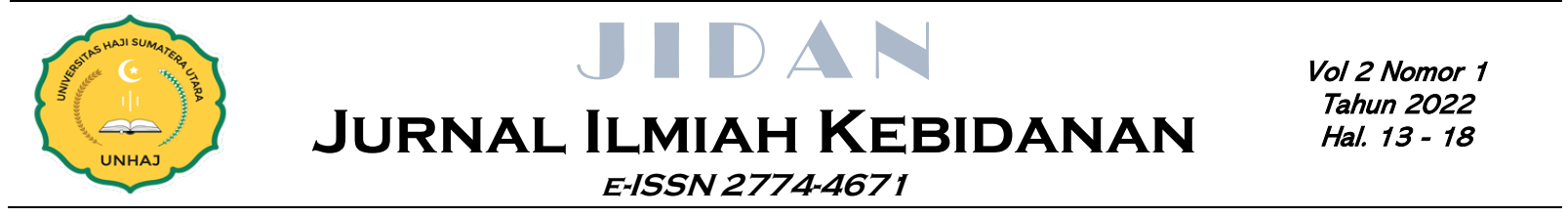

Dari tabel diatas dapat dilihat bahwa variabel bebas yang dapat masuk kedalam model multivariat adalah variabel Umur, Kadar Energi, Kadar protein, Kadar lemak,sedangkan variabel kadar Fe tidak masuk kedalam model multivariat karena mempunyai $\rho$ value $>0,25$.

\section{Persamaan Regresi Linier}

Adapun persamaan regrasi linier dapat dilihat pada tabel dibawah ini :

Tabel Model Summary

\begin{tabular}{|l|r|r|r|r|}
\hline Model & $\mathrm{R}$ & $\mathrm{R}$ Square & $\begin{array}{c}\text { Adjusted R } \\
\text { Square }\end{array}$ & Std. Error of the Estimate \\
\hline 1 & $0.699(\mathrm{a})$ & 0.489 & 0.430 & 0.767 \\
\hline
\end{tabular}

a Predictors: (Constant), Fe, Lemak, Protein

\begin{tabular}{|c|c|c|c|c|c|c|}
\hline \multicolumn{7}{|c|}{ ANOVA(b) } \\
\hline & & Sum of Squares & df & Mean Square & $\mathrm{F}$ & Sig. \\
\hline \multirow[t]{3}{*}{1} & $\begin{array}{l}\text { Regressio } \\
n\end{array}$ & 14.615 & 3 & \multirow{3}{*}{$\begin{array}{r}4.872 \\
.588\end{array}$} & \multirow[t]{3}{*}{8.289} & \multirow[t]{3}{*}{$.000(a)$} \\
\hline & Residual & 15.280 & 26 & & & \\
\hline & Total & 29.895 & 29 & & & \\
\hline
\end{tabular}

a Predictors: (Constant), Fe, Lemak, Protein

b Dependent Variable: $\mathrm{Hb}$

Coefficients(a)

\begin{tabular}{|c|c|c|c|c|c|c|}
\hline \multirow{2}{*}{\multicolumn{2}{|c|}{ Model }} & \multicolumn{2}{|c|}{$\begin{array}{c}\text { Unstandardized } \\
\text { Coefficients }\end{array}$} & \multirow{2}{*}{$\begin{array}{c}\begin{array}{c}\text { Standardized } \\
\text { Coefficients }\end{array} \\
\text { Beta }\end{array}$} & \multirow{2}{*}{$\begin{array}{l}\mathrm{T} \\
\mathrm{B}\end{array}$} & \multirow{2}{*}{$\begin{array}{c}\text { Sig. } \\
\text { Std. Error }\end{array}$} \\
\hline & & B & $\begin{array}{l}\text { Std. } \\
\text { Error }\end{array}$ & & & \\
\hline \multirow[t]{4}{*}{1} & (Constant) & $\begin{array}{r}11.12 \\
7\end{array}$ & 2.638 & & 4.218 & 0.000 \\
\hline & Protein & $0.020^{-}$ & 0.053 & -0.099 & -0.369 & 0.715 \\
\hline & Lemak & - & 0.047 & -0.223 & -1.218 & 0.234 \\
\hline & $\mathrm{Fe}$ & 0.211 & 0.085 & 0.668 & 2.488 & 0.020 \\
\hline
\end{tabular}

Dari tabel diatas pada kotak model summarry didapatkan nilai R Square sebesar 0,489, artinya kelima variabel indevenden dapat menjelaskan variabel kadar $\mathrm{Hb}$ sebesar 48,9\% sedangkan sisanya dijelaskan oleh variabel lain dari hasil uji statistik pada kotak anova didapatkan $\mathrm{p}$ value $=0,001$ berarti persamaan garis regresi secara keseluruhan sudah signifikan.

\section{Kesimpulan}

Berdasarkan data dan hasil uji hipotesis yang dilakukan pada ketiga hipotesis terdahulu, maka dapat ditarik kesimpulan ada pengaruh kadar energi dan protein sebelum dan sesudah dilakukan intervensi, tidak ada pengaruh kadar lemak, kadar Fe dan kadar Hb Sebelum dan Sesudah dilakukan Intervensi pada Remaja Putri di Sekolah Menengah Atas Swasta YPWI Muslimat dan persamaan garis regresi 0,001 berarti dapat disimpulkan secara keseluruhan sudah signifikan. 


\section{JURNAL ILMIAH KEBIDANAN \\ E-ISSN 2774-4671}

\section{Referensi}

Almatsier, Sunita, 2009. Prinsip Dasar Dalam Ilmu Gizi. PT Gramedia : Jakarta.

Amrullah, 2011. Hemoglobin (Kadar, Struktur, Cara Mengukur, Dll). Terdapat dalam http://.uinmalang.ac.id

Arisman. 2004. Gizi Dalam Daur Hidup. EGC : Jakarta.

Aryani, R, 2010. Kesehatan Remaja : Problem dan Solusinya. Penerbit Salemba Medika. Jakarta.

Astuti, Melani Puji, 2013. Tingkat Pengetahuan Remaja Putri Tentang Anemia Pada Siswi Kelas XI di SMA Muhammadiyah Sragen Tahun 2013.

Briawan, D. 2008. Efikasi suplementasi besi-multivitamin terhadap perbaikanstatus besi remaja wanita.Bogor : Sekolah Pasca Sarjana, Institut Pertanian Bogor.

Hardinsyah, Irawati, A, Kartono, D, Prihartini S, Linorita I, Amilia L,Fermanda M, Adyas EE, Yudianti D, Kusrto CM dan Heryanto Y(2012). Pola Konsumsi Pangan dan Gizi Penduduk Indonesia. Departemen Gizi Masyarakat FEMA IPB dan Badan Litbangkes Kemenkes RI. Bogor.

Kemenkes RI,2013 Tumbuh Kembang Anak,Jakarta.

--------------, 2014 .Angka Kecukupan Gizi.Direktorat Bina Gizi dan Kesehatan Ibu dan Anak,Jakarta.

Nita, Sandra, 2006. Hubungan Status Anemia Gizi Besi Dengan Prestasi Belajar Mahasiswa Jurusan Keperawatan Poltekes Jakarta 1,Skripsi, Fakultas Ilmu Kesehatan dan Fisioterapi Universitas Indonesia Esa Tunggal.

Proverawati, Asfuah, 2009. Ilmu Gizi Untuk Keperawatan Dan Gizi Kesehatan. Medical Book : Yogyakarta.

Riyadi H. 2001. Metode Penilaian Status Gizi Secara Antropometri.Bogor :Jurusan Gizi Masyarakat dan Sumberdaya Keluarga, Institut PertanianBogor.

Sadikin, 2002. Biokimia Darah. Widya Medika : Jakarta

Sediaoetama A.D, 2005. Ilmu Gizi Untuk Mahasiswa Dan Profesi. Jilid II : Dian Rakya : Jakarta.

Siti Maryam, Gizi dalam Kesehatan Reproduksi.Salemba Raya,2016.

Thompson B. 2007. Food-based approaches for combating iron deficiency.Didalam Nutritional Anemia, Edited by Klaus Kraemer \& Michael B.Zimmermann. Switzerland : Sight and Life Press. 